\title{
GENERAL PRINCIPLES OF ENVIRONMENTAL
} LAW

Luc Lavrysen, Ghent 5 February 2019

\section{A GLOBAL PACT FOR THE ENVIRONMENT ?}

- 1987: Our Common Future

- Universal declaration on environmental protection and sustainable development with basic environmental law principles (1988)

- Global Pact in second phase (1990-1993)

- Provisional principles - 22 Articles - International Lawyers - For consideration of UNGA as starting point for negotiations (Annex 1) 


\section{A GLOBAL PACT FOR THE ENVIRONMENT ?}

\section{- 1992: Rio Declaration}

- Nothing happens with Global Covenant Idea

- 1996: IUCN World Congress Montreal

- Recommendation for adopting an International Covenant on the Environment and Sustainable Development

- Draft International Covenant on Environment and Development

by IUCN Environmental Law Commission \& ICEL

\section{A GLOBAL PACT FOR THE ENVIRONMENT?}

- Updated on the occasion of each IUCN World Congress

- Fifth Edition 2015

\section{IUCN}

Draft

International Covenant on

Environment and Development

- Implementing Sustainability -

Fifth Edition: Updated Text 


\section{A GLOBAL PACT FOR THE ENVIRONMENT ?}

- Club des juristes (Paris) - 2015

- The 2030 Agenda for Sustainable Development

- SDGs

- Paris Accord

\section{REPORT SUMMARY}

ENVIRONMENT COMMITTEE - November 2015

\section{A GLOBAL PACT FOR THE ENVIRONMENT ?}

- COP 21 December 2015

- Chair Laurent FABIUS leaves active politics

- President of the Constitutional Council of France (March 2016)

- Chair of Expert Group for a Global Environmental pact - 150 lawyers - 50 countries

- SG: Yann AGUILA 


\section{THE PROCESS}

- Spring 2017 - 5 consecutive written consultations

- Preliminary Draft discussed and finalised on 23 June 2017 Constitutional Council
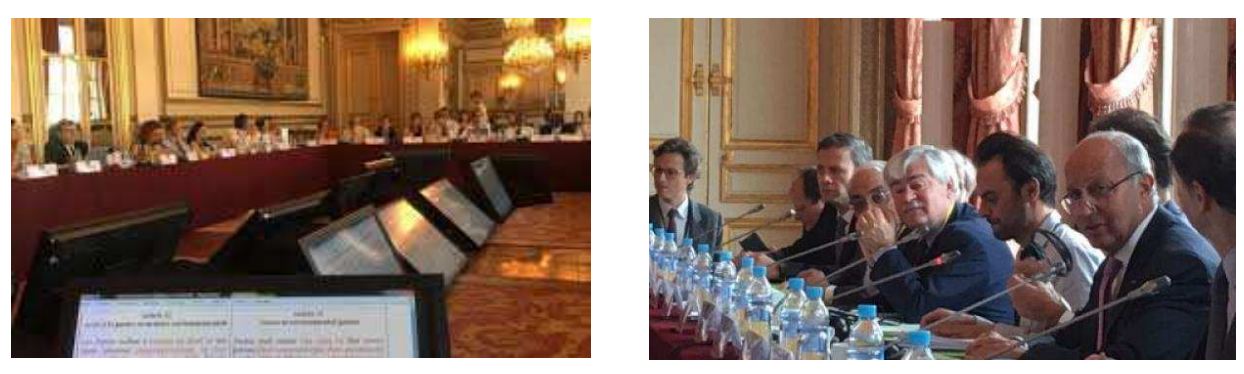

\section{THE DRAFT GLOBAL PACT - PRESENTATION}

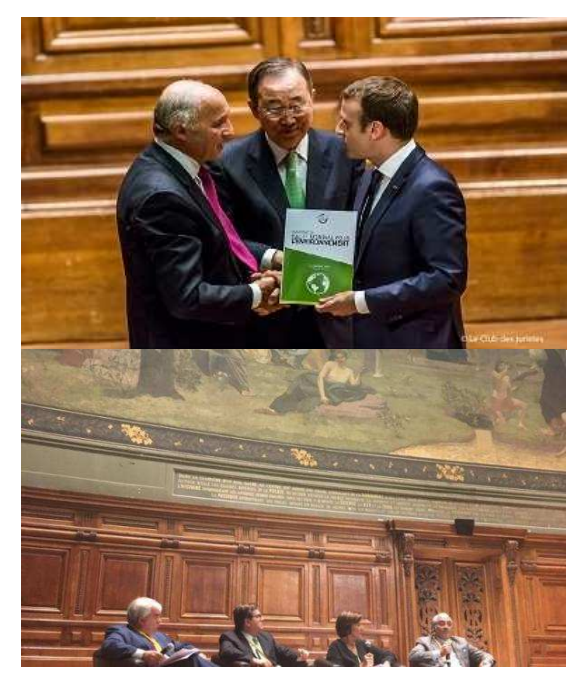




\section{THE CONTENT}

Art. 1. Right to an ecologically sound environment Art. 2. Duty to take care of the environment

Art. 3. Integration and sustainable development

Art. 4. Intergenerational Equity

Art. 5. Prevention

Art. 6. Precaution

Art. 7. Environmental Damages

Art. 8. Polluter-Pays

\section{THE CONTENT}

Art. 9. Access to information

Art. 10. Public Participation

Art. 11. Access to environmental justice

Art. 12. Education and training

Art. 13. Research and Innovation

Art. 14. Role of non-State actors and subnational entities

Art. 15. Effectiveness of environmental norms

Art. 16. Resilience 


\section{THE CONTENT}
Art. 17. Non-regression
Art. 18. Cooperation
Art. 19. Armed conflict
Art. 20. Diversity of national situations
Art. 21. Monitoring of the implementation of the Pact
Art. 22-26. Final provisions

\section{Comprehensive - Concise - Pragmatic Ambitious}

\section{PUTTING IT ON THE AGENDA}

- French Diplomacy

- President Macron is pushing for it

- UNGA

Seventy-second session

Agenda item 14

Resolution adopted by the General Assembly on 10 May 2018

[without reference to a Main Committee (A/72/L.51 and A/72/L.51/Add.1)]

72/277. Towards a Global Pact for the Environment 


\section{PUTTING IT ON THE AGENDA}

1. Kequests the Secretary-General to submit to the General Assembly at 1ts seventy-third session in 2018 a technical and evidence-based report that identifies and assesses possible gaps in international environmental law and environment-related instruments with a view to strengthening their implementation;

2. Decides to establish an ad hoc open-ended working group, under the auspices of the General Assembly, to consider the report and discuss possible options to address possible gaps in international environmental law and environment-related instruments, as appropriate, and, if deemed necessary, the scope, parameters and feasibility of an international instrument, with a view to making recommendations, which may include the convening of an intergovernmental conference to adopt an international instrument, to the Assembly during the first half of 2019;

3. Also decides that the ad hoc open-ended working group shall be open to participation by all States Members of the United Nations and all members of the specialized agencies;

(b) Substantive sessions, to be held in Nairobi, the first of which at least one month after the submission of the report of the Secretary-General;

\section{WHAT IS HAPPENING NOW ?}

United Nations

\section{General Assembly}

Distr.: General

30 November 2018

Original: English

ird session

m 14

1 and coordinated implementation of and follow-up to the outcomes of the major

tions conferences and summits in the economic, social and related fields

Gaps in international environmental law and environment-related instruments: towards a global pact for the environment

Report of the Secretary-General 


\section{WHAT IS HAPPENING NOW?}

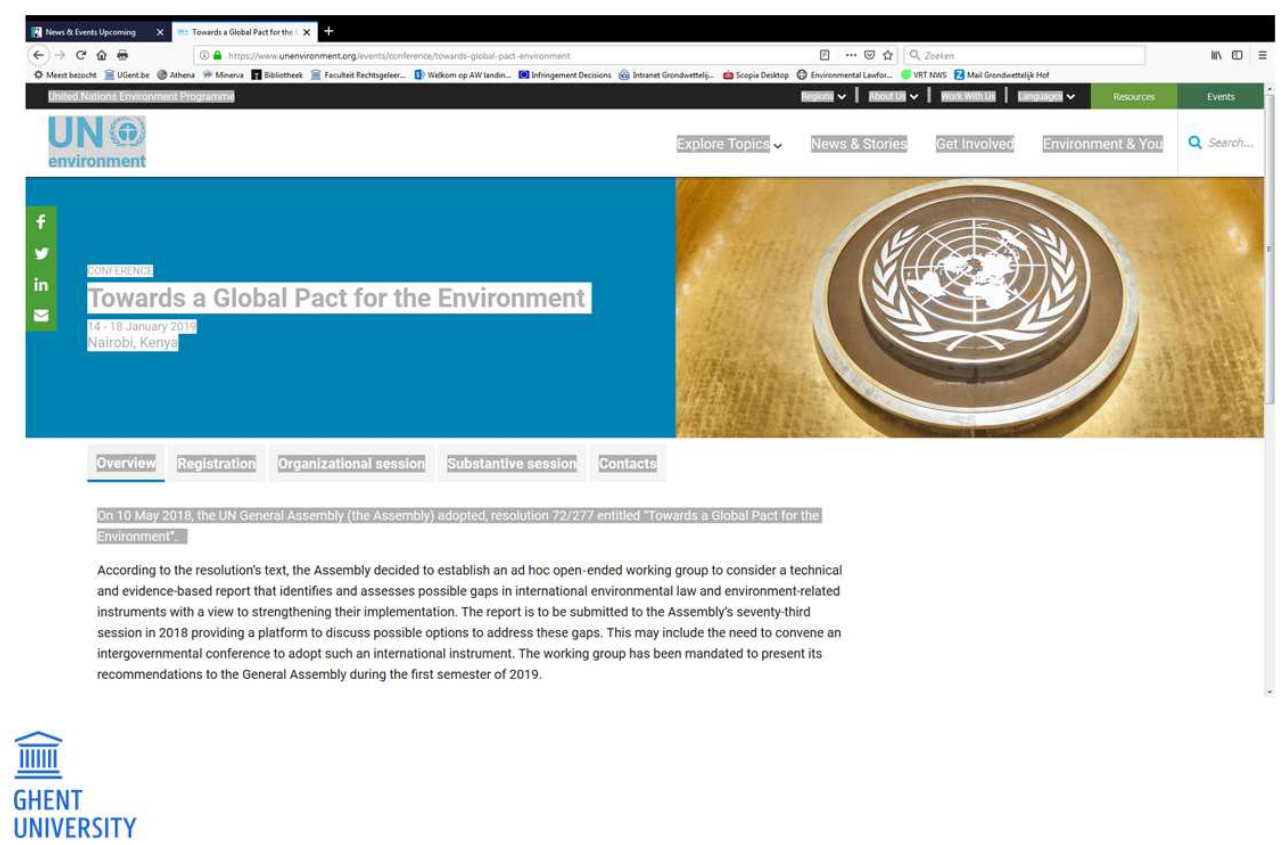

\section{WHAT IS HAPPENING NOW ?}

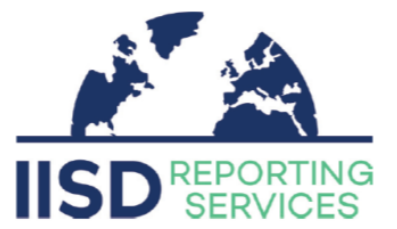

\section{Earth Negotiations Bulletin}

A Reporting Service for Environment and Development Negotiations

Vol. 35 No. 1

Online at: http://enb.iisd.org/unep/globalpact/oewg1/

Monday, 21 January 2019

Summary of the First Substantive Session of the $\boldsymbol{A d}$ group (OEWG) to consider a technical and evidence-based report Hoc Open Ended Working Group towards a Global

Pact for the Environment:

14-18 January 2019

The first substantive session of the $A d$ hoc Open-ended Working Group towards a Global Pact for the Environment convened on Monday, 14 January 2019 at the United Nations by the United Nations Secretary-General (UNSG) (A/73/419) identifying and assessing possible gaps in IEL and environmentrelated instruments with a view to strengthening their implementation. The resolution also recommends, if necessary, consideration of the scope, parameters, and feasibility of an international instrument, with a view to making recommendations that may include the convening of an intergovernmental 


\section{WHAT IS HAPPENING NOW?}

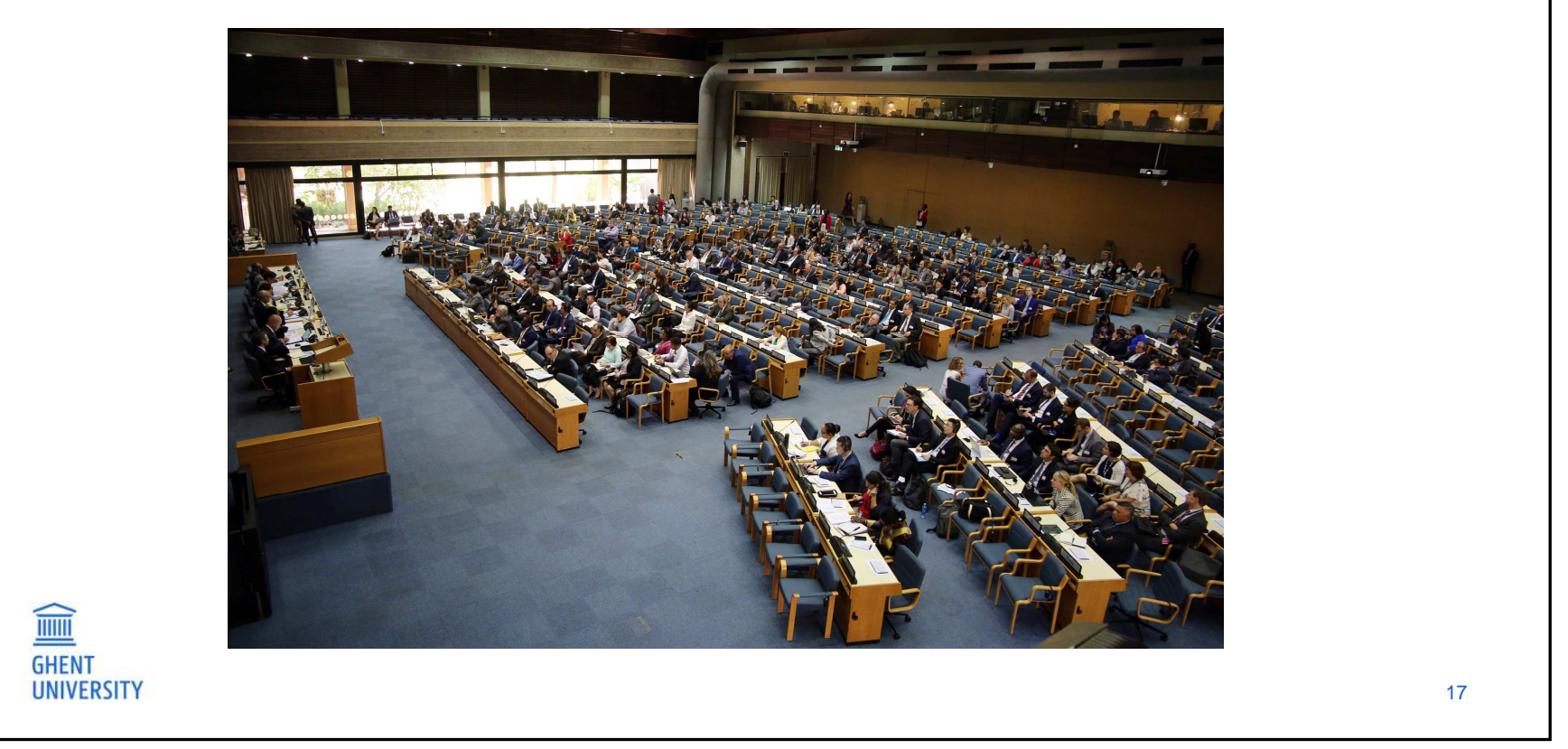

\section{WHAT IS HAPPENING NOW ?}

- Reluctance and opposition

- What is a Gap ? That is not a Gap !

- There are many more Gaps.....

- That is a justified Gap .....

- What will come out the second and third session?

- What will happen during next UNGA ?

- Are we to optimistic if we expect a Global Pact before 2050 ? 


\section{$\stackrel{T}{\text { FACULTY OF }}$ \\ $\triangleq \triangleq$ LAW AND CRIMINOLOGY \\ Luc Lavrysen}

Full Professor

Centre for Environmental and Energy Law

f Universiteit Gent

y @ugent

in Ghent University

E\luc.lavrysen@ugent.be

www.ugent.be

$\widehat{\underline{\underline{\text { IIIIII }}}}$

GHENT

UNIVERSITY 